\title{
MODEL PREDIKSI CURAH HUJAN DENGAN PENDEKATAN REGRESI PROSES GAUSSIAN (Studi Kasus di Kabupaten Grobogan)
}

\author{
Moch. Abdul Mukid, Sugito \\ Staf Pengajar Jurusan Statistika, Universitas Diponegoro \\ Email: mamukid@yahoo.com
}

\begin{abstract}
Forecasting method of rainfall has developed rapidly, ranging from the deterministic approach to the stochastic one. Deterministic approach is done through an analysis based on physical laws expressed in mathematical form, which identify the relationships between rainfall and temperature, air pressure, humidity and the intensity of solar radiation. Similarly, there are some stochastic models for the prediction of rainfall that have been commonly used, for instances, the model Autoregressive Integrated Moving Average (ARIMA), Fourier analysis and Kalman filter analysis. Some researchers about climate and weather have also developed a predictive model of rainfall based on nonparametric models, especially models based on artificial neural networks. Above models are based on classical statistical approach where the estimation and inference of model parameters only pay attention to the information obtained from the sample and ignore the initial information (prior) of parameter model. In this research, prediction model with Gaussian process regression approach is used for predicting the monthly rainfall. Gaussian process regression uses a stochastic approach by assuming that the amount of rainfall is random. Based on the value of Root Mean Square Error Prediction (RMSEP), the best covariance function that can be used for prediction is Quadratic Exponential ARD (Automatic Relevance Determination) with RMSEP value 123,63. The highest prediction of the monthly rainfall is in January 2014 reached into 336,5 $\mathrm{mm}$ and the lowest in August 2014 with 36,94 mm.
\end{abstract}

Key Words: Gaussian Procces Regression, Covariance Function, Rainfall Prediction

\section{Pendahuluan}

Kabupaten Grobogan adalah salah satu kabupaten di Provinsi Jawa Tengah. Ibukota kabupaten ini berada di Purwodadi. Secara geografis, wilayah Kabupaten Grobogan terletak di antara $110^{\circ} 15^{\prime}$ BT $-111^{\circ} 25^{\prime}$ BT dan $7^{\circ}$ LS - $7^{\circ} 30^{\prime}$ LS dengan kondisi tanah berupa daerah pegunungan kapur, perbukitan dan dataran di bagian tengahnya. Kabupaten Grobogan merupakan kabupaten terluas ke-2 di Jawa Tengah setelah Kabupaten Cilacap. Luas wilayahnya $1.975,865 \mathrm{~km}^{2}$ dan secara administratif terdiri 273 desa dan 7 kelurahan yang tersebar dalam 19 kecamatan $^{[5]}$.

Kabupaten yang berpenduduk sekitar 1,4 juta jiwa ini masih mengandalkan sektor pertanian untuk mendorong pertumbuhan ekonomi daerah dan kesejahteraan warganya. Sumbangan sektor pertanian terhadap produk domestik regional bruto (PDRB) pada 2010 mencapai $43 \%{ }^{[5]}$. Angka ini menunjukkan ketergantungan pendapatan penduduknya terhadap sektor pertanian yang masih sangat tinggi.

Sebagai salah satu lumbung pangan nasional, produksi padi di Kabupaten Grobogan tahun 2009 mencapai 696.110 ton sedangkan pada tahun 2010 produksi padi turun sebesar 4,9\% dari produksi tahun sebelumnya. Pada tahun 2011 produksi padi mencapai 602.477 ton Gabah Kering Giling (GKG) atau setara dengan 340.823 ton beras. Menurut kepala Dinas Pertanian Tanaman Pangan Hortikultura Kabupaten Grobogan, 
menurunnya produksi padi ini dipicu adanya serangan hama wereng dan kondisi iklim yang tidak stabil.

Perubahan iklim sebagai akibat pemanasan global telah mengakibatkan perubahan harmoni alam antara lain terjadinya peningkatan suhu udara, kenaikan tinggi air muka laut dan berubahnya pola hujan. Kondisi fluktuasi curah hujan yang tidak menentu pada beberapa tahun terakhir, menyebabkan perencanaan pertanian menjadi tidak optimal. Untuk mengantisipasi kerawanan pangan akibat hal tersebut, maka salah satu hal yang diperlukan adalah mengembangkan model prediksi curah hujan di wilayah yang mewakili sentra produksi pangan.

Seiring dengan berkembangnya teknologi modern, teknologi peramalan curah hujan juga sudah berkembang cukup pesat, mulai dari pendekatan yang sifatnya deterministik sampai dengan pendekatan secara stokastik ${ }^{[12]}$. Pendekatan secara deterministik dilakukan melalui analisis berdasarkan hukum-hukum fisika yang diekspresikan dalam bentuk persamaan matematik yang mengidentifikasi hubungan antara curah hujan dan suhu, tekanan udara, angin, kelembebaban udara serta intensitas penyinaran matahari. Sebaliknya terdapat beberapa model stokastik untuk prediksi curah hujan yang sudah umum digunakan, di antaranya, model Autoregressive Integrated Moving Average (ARIMA), analisis Fourier dan analisis Kalman Filter ${ }^{[8]}$. Beberapa peneliti mengenai iklim dan cuaca juga telah mengembangkan model prediksi curah hujan berdasarkan pada model-model nonparametrik, terutama model-model yang berbasiskan pada jaringan syaraf tiruan ${ }^{[15],[3],[11]}$.

Model-model di atas didasarkan pada pendekatan statistika klasik dengan pendugaan parameter model dan inferensinya hanya memperhatikan informasi dari sampel yang diperoleh dan mengabaikan informasi awal (prior) dari peneliti maupun petugas lapangan. Menurut Casella dan Berger, pendekatan klasik ini memiliki kelemahan dalam hal interpretasi terhadap selang kepercayaan dari parameter model ${ }^{[2]}$. Tingkat keyakinan terhadap kebenaran selang kepercayaan sebuah parameter model tidak dapat didasarkan pada taraf nyata yang ditetapkan sebelum model tersebut dibangun. Oleh karena itu, dalam penelitian ini akan digunakan sebuah model prediksi dengan pendekatan Nonparametric Bayesian. Kelebihan model-model nonparametrik terletak pada fleksibilitas bentuk dari modelnya, khususnya tidak terdapat asumsi pada bentuk parametriknya ${ }^{[4],[14]}$. Kelebihan model-model Bayesian terletak pada kemampuannya dalam mengakomodasi informasi awal yang dimiliki oleh peneliti. Kesimpulan akhir dari bentuk modelnya didasarkan tidak hanya pada informasi dari sampel tetapi juga didasarkan atas informasi subyektif dari peneliti. Informasi awal ini biasanya dikuantifikasi dalam bentuk distribusi dari parameter maupun fungsinya ${ }^{[1]}$.

Salah satu jenis model Nonparametric Bayesian adalah Regresi Proses Gaussian (RPG). Dalam hal ini fungsi-fungsi regresi diasumsikan berdistribusi normal ganda. Sebuah proses Gaussian secara lengkap ditentukan oleh fungsi rataan dan fungsi peragam. Menurut Rasmussen, fungsi peragam adalah fungsi dari input-input model yang menghasilkan sebuah nilai peragam bagi output-output yang bersesuaian dengan inputinput model tersebut ${ }^{[9]}$. Setiap fungsi peragam memiliki hyperparameter yang berbedabeda. Nilai hyperparameter ini tidak diketahui namun dapat diduga nilainya berdasarkan pada sampel yang diperoleh. Salah satu jenis fungsi peragam yang sering digunakan adalah fungsi eksponensial kuadrat (Gaussian). Fungsi ini termasuk dalam kategori isotropic, yaitu nilai kovarian tidak bergantung pada jarak antar intputnya ${ }^{[10]}$. Mukid et al., telah menggunakan model ini untuk membangun sebuah model kalibrasi bagi konsentrasi senyawa aktif kurkumin dan model prediksi bagi jumlah produksi kain di PT. APAC INTI 
CORPORA $^{[6] ;[7]}$. Model RPG ini menghasilkan nilai Root Mean Square Error (RMSE) yang cukup kecil jika dibandingkan dengan nilai rerata dari variabel responnya.

\section{Tinjauan Pustaka}

Di bagian ini akan dijelaskan berbagai hal yang berhubungan dengan curah hujan dan pemodelan Regresi Proses Gaussian.

\subsection{Hujan dan Variabel-Variabel yang Mempengaruhinya}

Curah hujan adalah banyaknya air yang jatuh ke permukaan bumi. Derajat curah hujan dinyatakan dengan jumlah curah hujan dalam suatu satuan waktu. Biasanya satuan yang digunakan adalah $\mathrm{mm} / \mathrm{jam}$. Dalam meteorologi butiran hujan dengan diameter lebih dari $0,5 \mathrm{~mm}$ disebut hujan dan diameter antara 0,5-0,1 $\mathrm{mm}$ disebut gerimis. Semakin besar ukuran butiran hujan maka semakin besar pula kecepatan jatuhnya. Ketelitian alat ukur curah hujan adalah 1/10 mm. Pembacaan dilakukan satu kali dalam sehari dan dicatat sebagai curah hujan hari terdahulu/kemarin ${ }^{[13]}$. Menurut Wilson, faktor yang mempengaruhi banyak curah hujan adalah kelembaban udara, tekanan udara, temperatur dan kecepatan angin ${ }^{[16]}$.

\subsection{Regresi Proses Gaussian}

Proses Gaussian adalah suatu proses stokastik dengan himpunan berhingga manapun dari himpunan peubah acak $Y$ mempunyai sebaran bersama Gaussian ganda ${ }^{[10]}$. Sebuah proses Gaussian secara lengkap ditentukan oleh fungsi rataan dan fungsi peragam $k\left(\mathbf{x}_{i}, \mathbf{x}_{j}\right)=E\left[\left(Y_{\mathbf{x}_{i}}-\mu\left(\mathbf{x}_{i}\right)\right)\left(Y_{\mathbf{x}_{j}}-\mu\left(\mathbf{x}_{j}\right)\right)\right]$.

\subsubsection{Model Dasar Regresi Proses Gaussian}

Regresi proses Gaussian dapat diturunkan dari sudut pandang regresi Nonparametric Bayesian yaitu dengan penempatan secara langsung sebaran prior Gaussian bagi fungsi-fungsi regresi $f(\mathbf{x})^{[10]}$. Misalkan untuk setiap output $y_{i}$ bergantung pada input $\mathbf{x}_{\mathrm{i}}$ di bawah sebuah fungsi $f_{i}$ sebagai berikut :

$$
y_{i}=f\left(\mathbf{x}_{i}\right)+\varepsilon_{i}
$$

dengan $\varepsilon_{i}$ adalah peubah acak galat yang secara bebas dan identik menyebar Gaussian dengan rataan nol dan ragam $\sigma^{2}$, sedangkan $\mathbf{x}_{i}$ adalah vektor input ke- $i$ dengan $i=$ $1, \ldots \ldots$, n. Apabila fungsi-fungsi $f$ dikumpulkan dalam sebuah vektor $\mathbf{f}=\left[f_{1}, \ldots, f_{n}\right]^{T}$ maka menurut Proses Gaussian untuk metode regresi, sebaran prior atas vektor $\mathbf{f}$ adalah Gaussian ganda dengan vektor rataan $\mathbf{0}$ dan matrik peragam $\mathbf{K}$, yaitu

$$
\mathbf{f} \mid \mathbf{X}, \boldsymbol{\theta} \sim N(\mathbf{0}, \mathbf{K})
$$

dengan $\mathbf{K}$ adalah matrik $\mathrm{n} \times \mathrm{n}$ yang bergantung pada $\mathbf{X}$ dan $\boldsymbol{\theta}$ sedangkan $\boldsymbol{\theta}$ adalah vektor parameter dari fungsi peragam. Setiap elemen ke $(i, j)$ dari matrik $\mathbf{K}$ adalah $k\left(\mathbf{x}_{i}, \mathbf{x}_{j}\right)$ dengan $k(.,$.$) adalah sebuah fungsi yang definit non negatif yang memuat parameter \boldsymbol{\theta}$. Selanjutnya $k(.,$.$) disebut sebagai fungsi peragam.$

Persamaan (1) dapat dinyatakan dalam bentuk persamaan vektor, yaitu

$$
\mathbf{y}=\mathbf{f}+\boldsymbol{\varepsilon}
$$

dengan $\mathbf{y}$ adalah vektor amatan dari respon, $\mathbf{f}$ adalah vektor dari fungsi-fungsi regresi dan $\boldsymbol{\varepsilon}$ adalah vektor galat.

Sebagai implikasi langsung atas penetapan sebaran prior Gaussian ganda bagi vektor $\mathbf{f}$ dan asumsi bahwa vektor galat $\boldsymbol{\varepsilon}$ menyebar Gaussian dengan nilai tengah $\mathbf{0}$ maka sebaran bagi vektor amatan $\mathbf{y}$ adalah Gaussian ganda dengan nilai tengah $\mathbf{0}$ dan matrik 
ragam peragam $\mathbf{K}+\sigma^{2} \mathbf{I}$. Tidak setiap vektor amatan $\mathbf{y}$ selalu memiliki nilai tengah $\mathbf{0}$ sehingga untuk memenuhinya setiap amatan dari $y_{\mathrm{i}}$ akan dikurangi dengan nilai rata-rata dari keseluruhan amatan.

\subsubsection{Fungsi Peragam}

Fungsi peragam adalah sebuah fungsi dari input-input model yang menghasilkan sebuah nilai peragam bagi output-output yang bersesuaian ${ }^{[9]}$. Satu-satunya syarat bagi sebuah fungsi kovarian adalah mampu membangkitkan sebuah matrik varian kovarian yang definit non negatif untuk sembarang himpunan titik-titik input. Fungsi-fungsi kovarian yang umum digunakan dalam model regresi proses Gaussian diantaranya adalah fungsi kovarian kuadrat eksponensial, fungsi kovarian linear dan fungsi kovarian dari kelas Matern.

Fungsi peragam lainnya dapat dibentuk dengan mengkombinasikan fungsi-fungsi kovarian di atas ${ }^{[10]}$. Dalam setiap fungsi kovarian mengandung beberapa parameter yang selanjutnya disebut dengan hyperparameter.

\subsubsection{Pendugaan Hyperparameter Fungsi Peragam}

Terdapat beberapa metode yang dapat digunakan untuk menduga nilai-nilai hyperparameter. Rassmusen dan William menyatakan bahwa untuk menduga nilai $\boldsymbol{\theta}$ dapat digunakan metode kemungkinan marginal maksimum ( Maximum Marginal Likelihood), metode aposterior maksimum, dan metode simulasi hybrid Monte Carlo ${ }^{[10]}$. Metode lain yang bisa digunakan adalah metode Cross Validation dan metode Generalized Cross Validation.

Dalam penelitian ini, pendugaan nilai hyperparameter menggunakan metode kemungkinan marginal maksimum. Fungsi kemungkinan marginal diperoleh dengan mengintegralkan fungsi kemungkinan yang telah dikalikan dengan sebaran prior bagi $\mathbf{f}$, yaitu

$$
p(\mathbf{y} \mid \mathbf{X}, \boldsymbol{\theta})=\int p(\mathbf{y} \mid \mathbf{f}, \mathbf{X}, \boldsymbol{\theta}) p(\mathbf{f} \mid \mathbf{X}, \boldsymbol{\theta}) d \mathbf{f}
$$

\subsubsection{Prediksi Dalam Regresi Proses Gaussian}

Misal diberikan beberapa amatan dan sebuah fungsi peragam. Selanjutnya akan ditentukan nilai prediksinya dengan menggunakan model proses Gaussian. Untuk melakukan hal itu, jika $\mathbf{x}^{*}$ sebuah titik uji dan $f^{*}$ adalah fungsi yang bersesuaian dengan $\mathbf{x}^{*}$, maka dibawah kerangka kerja Proses Gaussian, sebaran bersama dari $\mathbf{f}$ dan $f^{*}$ adalah Gaussian Ganda dengan rataan nol, yaitu:

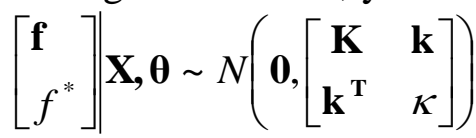

dengan $\mathbf{k}=\left[k\left(\mathbf{x}^{*}, \mathbf{x}_{1}\right), \ldots, k\left(\mathbf{x}^{*}, \mathbf{x}_{n}\right)^{T}\right.$ adalah vektor $\mathrm{n} \mathbf{x} 1$ yang dibentuk dari peragam antara $\mathbf{x}^{*}$ dan input-input model. Sedangkan $\kappa=k\left(\mathbf{x}^{*}, \mathbf{x}^{*}\right)$ adalah sebuah skalar. Apabila peubah galat mengikuti sebaran seperti pada Persamaan (1) maka sebaran bersama dari nilai teramati $\mathbf{y}$ dan $y^{*}$ adalah

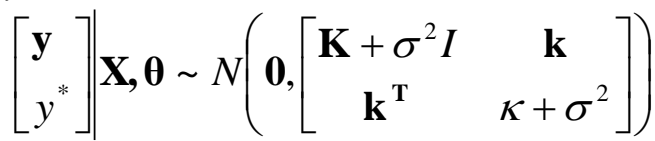

Sehingga sebaran marginal dari $y^{*}$ adalah Gaussian juga, yaitu :

$$
y^{*} \mid \mathbf{y}, \mathbf{X}, \boldsymbol{\theta} \sim N\left(m\left(\mathbf{x}^{*}\right), v\left(\mathbf{x}^{*}\right)\right)
$$


dengan rataan dan ragam adalah

$$
\begin{aligned}
& m\left(\mathbf{x}^{*}\right)=\mathbf{k}^{\mathbf{T}}\left(\mathbf{K}+\sigma^{2} \mathbf{I}\right)^{-1} \mathbf{y} \\
& v\left(\mathbf{x}^{*}\right)=\kappa+\sigma^{2}-\mathbf{k}^{\mathbf{T}}\left(\mathbf{K}+\sigma^{2} \mathbf{I}\right)^{-1} \mathbf{k}
\end{aligned}
$$

Nilai dugaan bagi $y^{*}$ adalah $m\left(\mathbf{x}^{*}\right)$ dan ragam bagi dugaan $y^{*}$ adalah $v\left(\mathbf{x}^{*}\right)$. Secara umum untuk $m$ buah titik uji $\mathbf{X}^{*}=\left[\mathbf{x}_{1}^{*}, \ldots, \mathbf{x}_{m}^{*}\right]$ maka sebaran $\mathbf{y}^{*}$ adalah Gaussian Ganda dengan parameter-parameter,

$$
\begin{aligned}
& m\left(\mathbf{X}^{*}\right)=\mathbf{K}^{* \mathbf{T}}\left(\mathbf{K}+\sigma^{2} \mathbf{I}\right)^{-1} \mathbf{y} \\
& v\left(\mathbf{X}^{*}\right)=\mathbf{K}^{* *}+\sigma^{2} \mathbf{I}-\mathbf{K}^{* \mathbf{T}}\left(\mathbf{K}+\sigma^{2} \mathbf{I}\right)^{-1} \mathbf{K}
\end{aligned}
$$

dimana $\mathbf{K}^{*}$ adalah matrik $n \times m$ dari peragam antara input-input training dan titik-titik uji. Matrik $\mathbf{K}^{* *}$ dengan ukuran $\mathrm{m} \times \mathrm{m}$ tersusun dari peragam antara titik-titik uji.

\section{Metode Penelitian}

1. Waktu dan Lokasi Penelitian

Penelitian ini dilakukan di Laboratorium Statistika, Jurusan Matematika, Fakultas Sains dan Matematika, Universitas Diponegoro. Untuk memperlancar pengolahan data, dalam penelitian ini digunakan software komputasi Matlab 2009 dan Minitab 15.

2. Variabel-variabel penelitian

Variabel-variabel yang diamati dalam penelitian ini adalah curah hujan, suhu, dan kelembaban udara. Adapun spesifikasi dari variabel-variabel tersebut dapat dilihat pada Tabel 1.

Tabel 1. Variabel Penelitian dan Satuan Pengukurannya

\begin{tabular}{clc}
\hline Nomor & \multicolumn{1}{c}{ Nama Variabel } & Satuan \\
\hline 1 & Curah hujan & $\mathrm{mm}$ \\
2 & Suhu & Celcius \\
3 & Kelembaban udara & $\mathrm{gr} / \mathrm{m}^{3}$ \\
\hline
\end{tabular}

\section{Sumber Data}

Data pada penelitian ini diperoleh dari Badan Meteorologi, Klimatologi, dan Geofisika (BMKG) propinsi Jawa Tengah. Data curah hujan, suhu, dan kelembaban udara yang digunakan adalah bulanan dari tahun 1980 sampai dengan 2013.

\section{Metode Analisis Data}

Terdapat beberapa tahapan dalam analisis data, yaitu:

1. Eksplorasi data, yaitu mengidentifikasi pola sebaran curah hujan dan variabelvariabel predictor yang diperhatikan.

2. Pendugaan nilai data yang hilang pada varaiabel-variabel penelitian

3. Membangun model dengan pendekatan regresi proses Gaussian berdasarkan variabel-variabel predictor dengan melakukan kajian terhadap beberapa fungsi peragam.

4. Melakukan validasi terhadap model hasil tahap 2 dengan kriteria Root Mean Square Error Prediction (RMSEP).

5. Membuat prediksi jumlah curah hujan bulanan tahun 2014. 


\section{Hasil Dan Pembahasan}

\subsection{Data Penelitian}

Menurut Wilson faktor yang mempengaruhi banyaknya curah hujan adalah kelembaban udara, tekanan udara, suhu dan kecepatan angin. Namun karena keterbatasan teknologi dan sumber daya manusia di Indonesia, tidak semua variabel tersebut tersedia di setiap daerah. Untuk Kabupaten Grobogan variabel yang tersedia hanyalah curah hujan, suhu dan kelembaban udara dengan rentang waktu dari tahun 1980 sampai dengan 2013. Runtun data ini dalam bentuk rata-rata bulanan. Namun demikian pada variabel curah hujan dan kelembaban udara, ada beberapa data yang hilang. Data yang hilang adalah jumlah curah hujan bulan Juni tahun 1980 dan kelembaban udara pada bulan Juli dan Agustus tahun 2004. Oleh karena itu sebelum digunakan untuk pembentukan model akan terlebih dahulu dilakukan pendugaan nilai data yang hilang tersebut.

Gambar 1 adalah grafik dinamika curah hujan bulanan dari tahun 1980 sampai dengan tahun 2013 setelah nilai data yang hilang diduga terlebih dahulu. Tampak bahwa keragaman jumlah curah hujan tahunan cukup tinggi. Simpangan bakunya mencapai hampir 149,70 mm. Jumlah curah hujan bulanan tertinggi terjadi pada bulan Nopember tahun 2010 yang mencapai $872 \mathrm{~mm}$.

Gambar 2 adalah grafik dinamika rata-rata suhu bulanan di Kabupaten Grobogan dari tahun 1980 sampai dengan tahun 2013. Secara umum rata-rata suhu tahunan di grobogan berada pada rentang $25^{\circ} \mathrm{C}$ sampai dengan $28^{\circ} \mathrm{C}$. Tampak bahwa kecenderungan suhu di Kabupaten Grobogan dari tahun 1980 sampai dengan tahun 1987 berada diatas $26^{\circ} \mathrm{C}$ sedangkan pada tahun-tahun berikutnya cenderung stabil pada kisaran $25,5^{\circ} \mathrm{C}$ meskipun masih memperlihatkan adanya keragaman yang kecil.

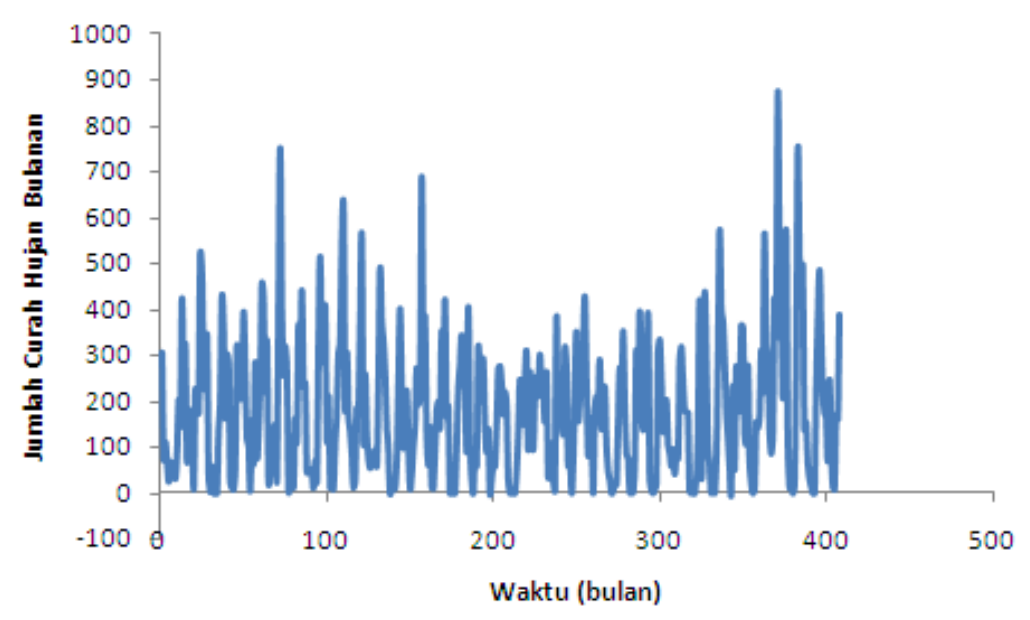

Gambar 1. Jumlah Curah Hujan Bulanan tahun 1980-2013 


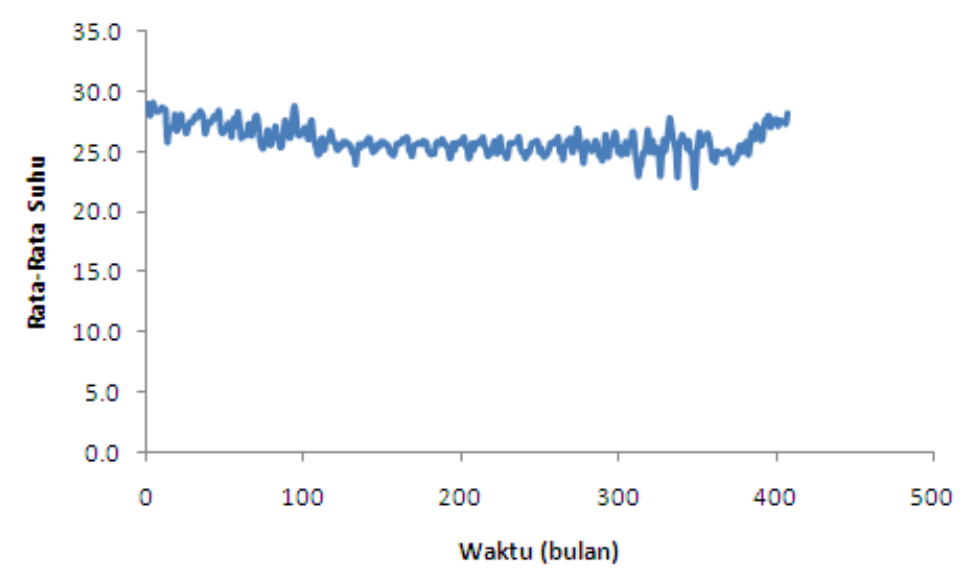

Gambar 2. Rata-rata Suhu Bulanan tahun 1980-2013

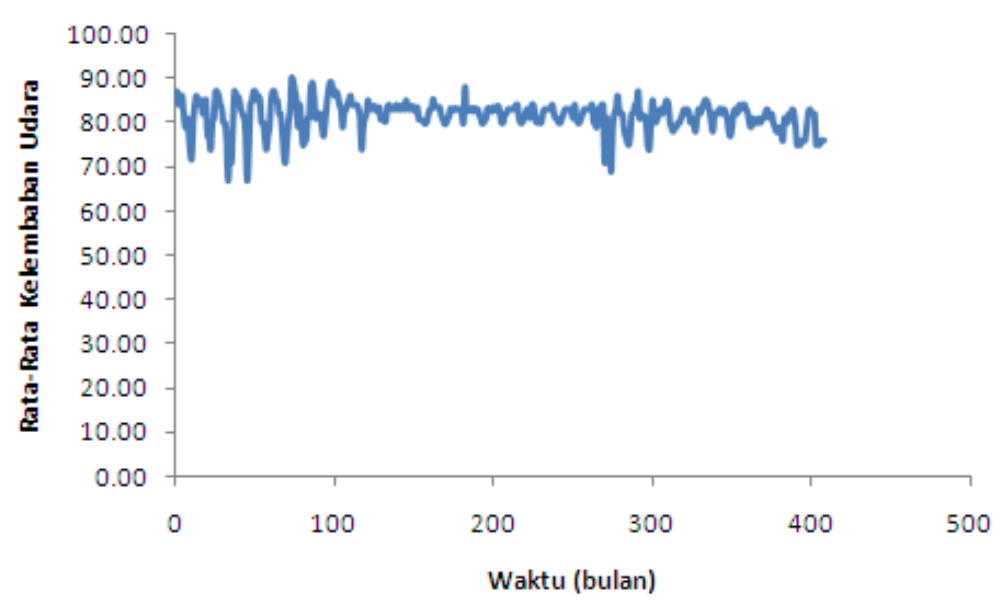

Gambar 3. Rata-rata Kelembaban Udara Bulanan tahun 1980-2013

Gambar 3 adalah grafik keadaan kelembaban udara di Kabupaten Grobogan dari tahun 1980 sampai dengan tahun 2013 setelah nilai data yang hilang diduga terlebih dahulu. Nilai kelembaban udara berfluktuatif dengan rentang dari $79 \mathrm{gr} / \mathrm{m}^{3}$ sampai dengan $85 \mathrm{gr} / \mathrm{m}^{3}$.

\subsection{Pendugaan Data Hilang}

Data hilang adalah informasi yang tidak tersedia untuk sebuah kasus (subyek). Ada beberapa alasan mengapa data tersebut dapat hilang diantaranya yaitu mungkin karena peralatan tidak berfungsi, cuaca buruk, atau data tidak dimasukkan dengan benar. Adanya data hilang menyebabkan data menjadi tidak lengkap.

Pada penelitian ini data yang hilang adalah jumlah curah hujan di bulan Juni tahun 1980 dan kelembaban udara di bulan Juli dan Agustus tahun 2004. Agar informasi yang diperoleh pada tahun yang sama tidak terbuang sia-sia maka pendugaan nilai data yang hilang tersebut perlu dilakukan. Pada penelitian ini nilai data tersebut diduga dengan mengambil nilai rata-rata pada keseluruhan pengamatan di bulan yang sama dengan nilai data yang hilang tersebut. hasil dugaannya ada di Tabel 2 dibawah ini. 
Tabel 2. Nilai Dugaan Data Hilang

\begin{tabular}{cllc}
\hline Tahun & Variabel & Bulan & Nilai Dugaan \\
\hline \multirow{2}{1}{980} & Curah Hujan & Juni & $67,88 \mathrm{~mm}$ \\
\hline \multirow{2}{*}{2004} & \multirow{2}{*}{ Kelembaban Udara } & Juli & $81,50 \mathrm{gr} / \mathrm{L}$ \\
& & Agustus & $80,44 \mathrm{gr} / \mathrm{L}$ \\
\hline
\end{tabular}

\subsection{Pemilihan Fungsi Peragam}

Fungsi peragam yang dikaji dalam penelitian ini adalah

1. Fungsi peragam kuadrat eksponensial dengan ukuran jarak isotropik (KE-iso).

2. Fungsi peragam kuadrat eksponensial dengan ukuran jarak Automatic Relevance Determination (KE-ARD).

3. Fungsi peragam linear dengan hiperparameter tunggal (Linear-1).

4. Fungsi peragam linear dengan parameter Automatic Relevance Determination (LinearARD).

Setelah fungsi-fungsi peragam di atas dicobakan untuk digunakan dalam pemodelan regresi Proses Gaussian, hasil selengkapnya ada di Tabel 3. Dari Tabel 3 diketahui bahwa nilai RMSEP terkecil diperolah ketika model regresi Proses Gaussian menggunakan fungsi peragam Kuadrat eksponensial ARD, yaitu sebesar 123,63. Selanjutnya fungsi peragam ini akan digunakan untuk melakukan prediksi jumlah curah hujan di tahun 2014.

Tabel 3. Nilai Dugaan Hyperparameter Fungsi Peragam dan RMSEP

\begin{tabular}{llrl}
\hline \multicolumn{1}{c}{ Fungsi Peragam } & \multicolumn{1}{c}{ Hyperparameter } & $\begin{array}{r}\text { Dugaan } \\
\text { Parameter }\end{array}$ & RMSEP \\
\hline Kuadrat eksponensial & Skala Panjang & 8970,86 & \\
isotropic & Ragam Signal & 1,27 & \multirow{2}{*}{126,40} \\
& Ragam Galat & 16217,49 & \\
\hline \multirow{2}{*}{ Kuadrat eksponensial } & Skala Panjang 1 & 1,11 & \\
ARD & Skala Panjang 2 & 0,01 & \multirow{2}{*}{123,63} \\
& Ragam Signal & 8064,11 & \\
& Ragam Galat & 16024,55 & \\
\hline \multirow{2}{*}{ Linear ARD } & Parameter Pengendali Bias 1 & 0,04 & \multirow{2}{*}{0} \\
& Parameter Pengendali Bias 2 & 0,13 & \multirow{2}{*}{128,90} \\
& Ragam galat & 20788,30 & \\
\hline Linear One & Parameter Pengendali Bias & 0,05 & \multirow{2}{*}{128,87} \\
& Ragam Galat & 20788,30 & \\
\hline
\end{tabular}

\subsection{Prediksi Curah Hujan Tahun 2014}

Sebelum melakukan prediksi terhadap jumlah curah hujan bulanan selama tahun 2014 terlebih dahulu dilakukan prediksi untuk rata-rata suhu dan kelembaban udara selama 12 bulan tahun 2014. Dalam hal ini metode yang digunakan adalah rata-rata bergerak dengan periode 3 . Hasil prediksinya ada di Tabel 4. 
Tabel 4. Prediksi Suhu dan Kelembaban Udara Tahun 2014

\begin{tabular}{lcc}
\hline \multirow{2}{*}{ Bulan } & \multicolumn{2}{c}{ Variabel } \\
\cline { 2 - 3 } & Suhu & $\begin{array}{c}\text { Kelembaban } \\
\text { Udara }\end{array}$ \\
\hline Januari & 23,57 & 80,33 \\
Pebruari & 24,37 & 81,67 \\
Maret & 25,13 & 82,00 \\
April & 25,50 & 81,67 \\
Mei & 25,33 & 81,00 \\
Juni & 25,47 & 79,67 \\
Juli & 25,43 & 76,00 \\
Agustus & 25,50 & 76,67 \\
September & 25,77 & 76,00 \\
Oktober & 25,77 & 76,00 \\
Nopember & 25,03 & 77,67 \\
Desember & 24,77 & 77,33 \\
\hline
\end{tabular}

Dari Tabel 4 diketahui bahwa berdasarkan prediksi, rata-rata suhu bulanan tertinggi sebesar $25,77^{\circ} \mathrm{C}$ jatuh pada September dan Oktober 2014 dan terendah pada bulan Januari 2014 sebesar 23,57. Sedangkan untuk kelembaban udara, berdasarkan prediksi, nilai tertinggi ada di bulan Maret 2014 yaitu sebesar $82,00 \mathrm{gr} / \mathrm{m}^{3}$ dan terendah ada di bulan Juli, Sepetember dan Oktober 2014 yang mencapai 76,00 gr $/ \mathrm{m}^{3}$.

Hasil-hasil prediksi pada variabel suhu dan kelembaban udara untuk tahun 2014 akan menjadi input bagi kepentingan prediksi jumlah curah hujan di tahun 2014 dengan menggunakan model regresi Proses Gaussian. Prediksi curah hujan untuk 12 bulan dengan menggunakan model regresi Proses Gaussian ada di Tabel 5. Dari Tabel 5 tampak bahwa prediksi rata-rata curah hujan tertinggi ada di bulan Januari yang mencapai 336,5 mm dengan keragaman sebesar 129,36 mm dan terendah di bulan Agustus 2014 sebesar 36,94 dengan keragaman sebesar 67,36.

Tabel 5. Prediksi Jumlah Curah Hujan tahun 2014

\begin{tabular}{lcc}
\hline \multicolumn{1}{c}{ Bulan } & $\begin{array}{c}\text { Curah } \\
\text { Hujan }\end{array}$ & $\begin{array}{c}\text { Simpangan } \\
\text { Baku }\end{array}$ \\
\hline Januari & 336,50 & 129,36 \\
Pebruari & 257,94 & 126,66 \\
Maret & 259,50 & 103,52 \\
April & 201,50 & 107,69 \\
Mei & 126,65 & 99,44 \\
Juni & 67,88 & 67,42 \\
Juli & 49,44 & 47,43 \\
Agustus & 36,94 & 67,36 \\
September & 84,09 & 97,77 \\
Oktober & 161,77 & 106,48 \\
Nopember & 253,50 & 175,76 \\
Desember & 333,00 & 146,18
\end{tabular}




\section{Kesimpulan}

Seiring dengan berkembangnya teknologi modern, teknologi peramalan curah hujan juga sudah berkembang cukup pesat, mulai dari pendekatan yang sifatnya deterministik sampai dengan pendekatan secara stokastik. Regresi proses Gaussian menggunakan pendekatan secara stokastik dengan menganggap bahwa besaran curah hujan bersifat acak. Berdasarkan nilai Root Mean Square Prediction (RMSEP), fungsi peragam terbaik yang dapat digunakan untuk prediksi adalah Kuadrat Eksponensial ARD dengan RMSEP sebesar 123,63. Prediksi jumlah curah hujan tertinggi ada di bulan Januari yang mencapai 336,5 mm dengan simpangan 129,36 mm dan terendah di bulan Agustus 2014 sebesar 36,94 dengan simpangan baku sebesar 67,36.

\section{DAFTAR PUSTAKA}

1. Box G.E.P and George C.T., Bayesian Inference in Statistical Analysis, AddisonWesley Publishing Company, Inc. Canada, 1973.

2. Casella G. and Berger R.L., Statistical Inference, Second Ed. Thomson Learning, Duxbury, 2002.

3. Estiningtyas W., Elsa S., dan Kharmila S.H., Penyusunan Skenario Masa Tanam Berdasarkan Prakiraan Curah Hujan di Sentra Produksi Pangan, Jurnal Meteorologi dan Geofisika, 2008, Vol. 9, No.2: 65-77.

4. Eubank R.L., Nonparametric Regression and Spline Smoothing, Second Ed. Marcel Deker, Inc. New York, 1999.

5. Grobogan Dalam Angka Tahun 2010.

6. Mukid, M.A., Aji H.W., dan Erfiani, Kinerja Regresi Proses Gaussian Untuk Pemodelan Kalibrasi Peubah Ganda Pada Daerah Identifikasi Spektra Infra Merah Senyawa Aktif, Prosiding Seminar Nasional Statistika IX ITS, 2009. Surabaya, 7 Nopember 2009.

7. Mukid M.A., Pemodelan Regresi Proses Gaussian Menggunakan Fungsi Peragam Eksponensial Kuadrat, Media Statistika, 2010, Vol.3, No.1:1-7.

8. Pramudia A., Yonny K., Irsal L., dan Tania J., Pewilayahan Hujan dan Model Prediksi Curah Hujan untuk Mendukung Ananlisis Ketersediaan dan Kerentanan Pangan di Sentra Produksi Padi, Forum Pascasarjana, 2008, Vol. 31, No. 2: 131-142.

9. Rasmussen C.E., Evaluation of Gaussian Processes and Other Methods for Non-linear Regression (Disertasi), Department of Computer Science, University of Toronto. 1996.

10. Rasmussen C.E. and Williams C.K.I., Gaussian Process for Machine Learning, MIT Press, Massachusetts, 2006.

11. Subarna D., Aplikasi Jaringan Neural untuk Pemodelan dan Prediksi Curah Hujan, Berita Dirgantara, 2009, Vol.10, No.1: 13-18.

12. Sutikno, Rokhana D.B, Putri S, dan Istriana, Prakiraan Cuaca dengan Metode Autoregressive Integrated Moving Average, Neural Network dan Adaptive Splines Treshold Autoregression di Stasiun Juanda Surabaya, Jurnal Sains Dirgantara, 2010, Vol. 8, No. 1: 43-61.

13. Soewarno, Hidrologi Operasional, Citra Aditya Bakti, Bandung, 2000.

14. Takezawa K., Introduction to Nonparametric Regression, John Wiley \& Sons, New Jersey, 2006: 1-15.

15. Warsito B. dan Sri S., Prediksi Curah Hujan Kota Semarang dengan Feedforward Neural Network Menggunakan Algoritma Quasi Newton BFGS dan LevenbergMarquardt, Jurnal Presipitasi, 2007, Vol. 3, No.2: 60-64.

16. Wilson, E.M., Hidrologi Teknik, Erlangga, Jakarta, 1993. 